\title{
Tadeusz Borys
}

Uniwersytet Zielonogórski

e-mail: tadeusz.borys@ue.wroc.pl

\section{REKOMENDACJA KSIĄŻKI \\ PT. SYSTEMY ZARZADZANIA W ZNORMALIZOWANYM \\ ŚWIECIE POD REDAKCJĄ NAUKOWA \\ JERZEGO LAŃCUCKIEGO}

DOI: $10.15611 /$ nit.2018.3.05

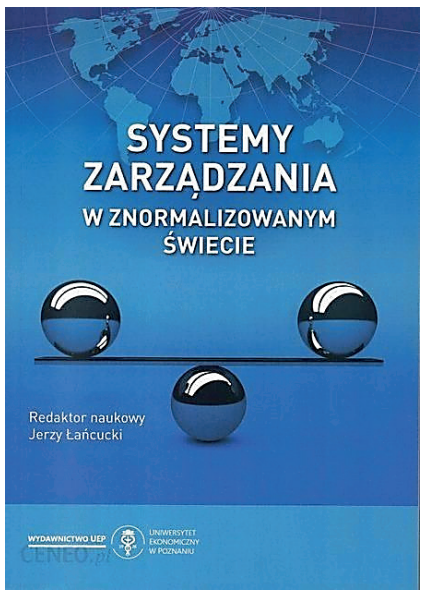

Polecam z całym przekonaniem bardzo ciekawą i prezentującą odpowiedni poziom naukowy książkę, która ma spełniać funkcję podręcznika przeznaczonego do wykorzystania w procesie dydaktycznym wyższych uczelni oraz $\mathrm{w}$ praktyce przez kadrę kierowniczą organizacji różnego typu. To właśnie kryterium przydatności dydaktycznej tej pracy zadecydowało o zarekomendowaniu tego podręcznika jak najszerszemu kręgowi odbiorców. Stwierdzam przede wszystkim dużą zgodność tytułu z treścią poszczególnych części pracy. Autorzy pracy rozdziałami i podrozdziałami wypełniają zakres tematyczny zapowiedziany w tytule książki poświęconej znormalizowanemu podejściu do systemów zarządzania, rozpatrywanemu w tej pracy w różnych kontekstach.

Ta trochę nietypowa dla podręcznika część tytułu („w znormalizowanym świecie") jest jednak uzasadniona powszechnością normalizowania działalności ludzkiej w obecnej cywilizacji. Przedmiotem książki, a jednocześnie jej głównym celem jest możliwie kompleksowe przedstawienie różnych aspektów teoretycznych i praktycznych procesów normalizowania systemów zarządzania w kontekście dobrych praktyk zarządzania w odniesieniu do jakości, środowiska, ryzyka, bezpieczeństwa i higieny pracy, bezpieczeństwa informacji i żywności oraz społecznej odpowiedzialności, a także procesów audytowania.

We wstępie uzasadniono profil merytoryczny pracy, będącej próbą całościowego ukazania systemów zarządzania objętych procesem normalizacji. Procesy te uka- 
zane są jako użyteczne narzędzie, które jest wykorzystywane w zarządzaniu organizacją, a poziom tej użyteczności - co ma fundamentalne znaczenie i jest mocno akcentowane we wstępie - zależy przede wszystkim od kompetencji, umiejętności, doświadczenia i zaangażowania ludzi, którzy z tego narzędzia zechcą skorzystać. Zgadzam się generalnie $\mathrm{z}$ tezą o pseudonaukowości analiz zapisów określonych norm w ramach „rozlewającego się” we współczesnym świecie - jak to nazwano w pracy - „normocentryzmu”, choć moim zdaniem, z perspektywy praktyki stosowania tych norm, nie każdą taką analizę należy uznać za przedsięwzięcie jałowe.

Strukturę pracy tworzy dziesięć rozdziałów, które nadają pracy komplementarny charakter i układ treści.

W rozdziale pierwszym, który jest poświęcony omówieniu roli i znaczenia norm i normalizacji we współczesnym świecie, przedstawione są kolejno: cele normalizacji i jej wpływ na gospodarkę, ważniejsze aspekty jej instytucjonalizacji, pojęcie normy i jej klasyfikacje, ważniejsze bariery normalizacji na przykładzie europejskiego systemu normalizacyjnego, rola normalizacji w dwóch wybranych sektorach: usługach i technologii informacyjno-komunikacyjnych (ICT) i rola norm jako narzędzia podnoszenia skuteczności zarządzania organizacją.

Rozdział drugi poświęcony jest opisowi podstaw zarządzania jakością. To szczególnie ważny rozdział tej pracy, powszechnie bowiem uznawany za prekursorski w obszarze systemów znormalizowanych. W rozdziale tym przedstawiono kolejno: pojęcie jakości, ponownie eksponowany jest sektor usług w podrozdziale „Jakość w usługach", znormalizowany system zarządzania jakością według norm ISO serii 9000 i problemy jakości organizacji, jej trwałego sukcesu, kontekstu i tożsamości.

Rozdzial trzeci poświęcony jest charakterystyce systemów zarządzania środowiskowego. Autorka tego rozdziału przedstawia kolejno: istotę i genezę podejścia systemowego do zarządzania środowiskowego, systemy zarządzania środowiskowego według norm ISO serii 14000 i EMAS, etapy wdrażania systemu, podobieństwa i różnice między wymienionymi systemami oraz pokrewny w sensie środowiskowym system zarządzania energią.

W rozdziale czwartym przedstawiono istotę i zakres stosowania zarządzania środowiskowym cyklem życia wyrobów i organizacji. Problematyka tego rozdziału, wyraźnie nawiązującego do rozdziału poprzedniego, obejmuje kolejno: przypomnienie standardów zarządzania środowiskowego, określenie istoty środowiskowej oceny cyklu życia, zakres stosowania tej oceny i koncepcję uproszczonej oceny do celów ekoprojektowania.

Rozdzial piąty poświęcony jest systemowemu zarządzaniu bezpieczeństwem informacji. Przedstawiono w nim zagadnienia wprowadzające do zarządzania bezpieczeństwem informacji i znaczenie informacji oraz jej bezpieczeństwa, istotę bezpieczeństwa informacji, zabezpieczenia $\mathrm{w}$ systemie, koncepcję $\mathrm{i}$ rolę $\mathrm{w}$ systemie bezpieczeństwa, identyfikację i klasyfikację informacji, szacowanie i postępowanie $\mathrm{z}$ ryzykiem $w$ systemie zarządzania bezpieczeństwem informacji, plan ciągłości działania, identyfikację aktów informacyjnych infrastruktury i dokumentację w tym systemie oraz monitorowanie i przegląd systemu oraz rekomendacje w jego budowie. 
W rozdziale szóstym przedstawiona jest ważna problematyka zarządzania bezpieczeństwem żywności - jako kontynuacja tematu bezpieczeństwa (z rozdziału piątego), ale tym razem w odniesieniu do bezpieczeństwa żywnościowego. Zakres tematyczny tego rozdziału obejmuje kolejno następujące cztery problemy: wymagania prawne dotyczące bezpieczeństwa żywności, identyfikację zagrożeń w łańcuchu żywnościowym, opis systemu zarządzania bezpieczeństwem żywności oraz opis systemu TACCP.

W rozdziale siódmym zaprezentowano kolejny, trzeci już aspekt bezpieczeństwa $\mathrm{w}$ systemach, tym razem dotyczący pracy, przy założeniu, że higiena jest $\mathrm{w}$ istocie rzeczy elementem bezpieczeństwa. Zakres tematyczny tego rozdziału obejmuje kolejno pięć następujących problemów: podstawy prawne dotyczące bhp, ewolucję systemów bhp, prezentację systemów zarządzania bhp, korzyści i problemy związane z tym zarządzaniem, praktyczne aspekty systemowego podejścia do bhp.

Rozdzial ósmy poświęcony jest przedstawieniu podejścia do projakościowego zarządzania organizacją opartego na ryzyku. Autor tego rozdziału kolejno przedstawia: architekturę projakościowego zarządzania organizacją, istotę podejścia do zarządzania jakością opartego na ryzyku i podstawowe uwarunkowania powodzenia działań projakościowych.

$\mathrm{W}$ rozdziale dziewiątym przedstawiono kluczowe narzędzie badania systemu zarządzania w organizacji, a mianowicie problematykę audytów. Zakres tematyczny tego rozdziału tworzy osiem najważniejszych i logicznie uporządkowanych problemów związanych z samym pojęciem audytu i procesem audytowania, dotyczących: pojęcia audytu, zasad i metod audytowania, zarządzania programem audytów, przeprowadzania audytu, wykonywania raportu z jego przebiegu i zakończenia audytu oraz przeprowadzania audytu kontrolnego.

Rozdział dziesiąty poświęcony jest - zgodnie z jego tytułem - roli działań normalizacyjnych w zarządzaniu społecznie odpowiedzialnym. Jest to zwięźle przedstawiony i potrzebny rozdział, który zamyka ciąg merytoryczny tego podręcznika poświęcony nurtowi normalizacyjnemu w naukach o zarządzaniu na poziomie organizacji. Autor tego rozdziału kolejno przedstawia: istotę, bariery i korzyści wprowadzania w życie koncepcji CSR, rolę interesariuszy w tej koncepcji oraz pięć inicjatyw działań normalizacyjnych i porozumień „wspomagających” odnoszących się do zarządzania społecznie odpowiedzialnego.

Praca ta wyróżnia się więc na tle innych publikacji z tego zakresu kompleksowością podejścia do coraz bardziej rozprzestrzeniającego się zjawiska obejmowania procedurą normalizacyjną kolejnych obszarów działalności człowieka. Proces ten właściwie wykorzystany - może przynieść wiele korzyści w zarządzaniu organizacją, ale też powoduje potencjalne, a także realne zagrożenia związane przede wszystkim z odhumanizowaniem i ograniczaniem kreatywności rozwoju systemów zarządzania. Obecnie na polskim rynku wydawniczym przeważają ujęcia wąskie, wyspecjalizowane, czyli ograniczające problematykę normalizacyjną do poszczególnych obszarów tematycznych, w tym m.in. obszarów jakości, środowiska, ryzyka. 